\title{
Healthy Eating Policy Improves Children's Diet Quality in Early Care and Education in South Carolina
}

\author{
Daniel A. Zaltz ${ }^{1, *}$, Amelie A. Hecht ${ }^{2}$, Roni A. Neff ${ }^{3,4}$, Russell R. Pate ${ }^{5}$, Brian Neelon ${ }^{6}$, \\ Jennifer R. $\mathrm{O}^{\prime}$ Neill $^{5}$ and Sara E. Benjamin-Neelon ${ }^{1}$ D \\ 1 Department of Health, Behavior and Society, Johns Hopkins Bloomberg School of Public Health, \\ 615 N Wolfe St, Baltimore, MD 21205, USA; sara.neelon@jhu.edu \\ 2 Department of Health Policy and Management, Johns Hopkins Bloomberg School of Public Health, \\ 615 N Wolfe St, Baltimore, MD 21205, USA; ahecht3@jhu.edu \\ 3 Johns Hopkins Center for a Livable Future, Johns Hopkins Bloomberg School of Public Health 111 Market Pl, \\ Suite 840, Baltimore, MD 21202, USA; rneff1@jhu.edu \\ 4 Department of Environmental Health \& Engineering, Johns Hopkins Bloomberg School of Public Health, \\ 615 N Wolfe St, Baltimore, MD 21205, USA \\ 5 Department of Exercise Science, University of South Carolina Arnold School of Public Health, 921 Assembly \\ St, Columbia, SC 29208, USA; RPATE@mailbox.sc.edu (R.R.P.); ONEILLJR@mailbox.sc.edu (J.R.O.) \\ 6 Division of Biostatistics, Department of Public Health Sciences, Medical University of South Carolina, \\ 135 Cannon St, Charleston, SC 29415, USA; neelon@musc.edu \\ * Correspondence: dzaltz1@jhu.edu
}

Received: 11 May 2020; Accepted: 9 June 2020; Published: 11 June 2020

\begin{abstract}
Policies to promote healthy foods in early care and education (ECE) in the United States exist, but few have been prospectively evaluated. In South Carolina, a statewide program serving low-income children in ECE enacted new policies promoting healthy foods. We conducted an evaluation to measure changes in dietary intake among children in ECE exposed and not exposed to the new policy. Using direct observation, we assessed dietary intake in 112 children from 34 ECE centers in South Carolina and 90 children from 30 ECE centers in North Carolina (a state with no policy). We calculated Healthy Eating Index-2015 (HEI) scores to measure diet quality consumed before and after the policy was enacted. We fit mixed-effects linear models to estimate differences in HEI scores by state from baseline to post-policy, adjusting for child race, number of children enrolled, director education, center years in operation, participation in the Child and Adult Care Food Program (CACFP), and center profit status. The policy increased HEI scores for whole fruits, total fruits, and lean proteins, but decreased scores for dairy. Thus, the policy was associated with some enhancements in dietary intake, but additional support may help improve other components of diet.
\end{abstract}

Keywords: policy; healthy eating; early care and education

\section{Introduction}

The global prevalence of childhood overweight and obesity significantly increased over the past four decades [1], contributing to vast social, economic, and health burdens [2]. Children with overweight or obesity are at an increased risk of chronic conditions, including high blood pressure [3], asthma [4], and type 2 diabetes [5], as well as persistent obesity [6], stigma and related mental health outcomes [7], and cardiovascular diseases in adulthood [8,9]. Early childhood is a critical intervention period to prevent obesity and reduce potential negative health impacts later in life [10].

Policies that promote healthy eating have the ability to reach broad audiences and influence obesogenic behaviors with relatively low resource utilization [11], and thus play a central role in global childhood obesity prevention [12]. The early care and education setting (ECE) is one such venue to 
implement these policies [13], given that the majority of children ages 3 to 5 years in most Western countries regularly attend ECE, where they are likely to receive a significant portion of their daily meals and snacks [14,15]. There is some evidence that children attending ECE have a higher prevalence of obesity than others [16-18]. Moreover, children may receive inadequate servings of fruits, vegetables, and whole grains in ECE, as well as excessive amounts of saturated fats and added sugars [19-22]. Policies designed to improve diet quality in ECE may have long term benefits, since dietary intake during early childhood impacts eating habits and health outcomes throughout life [23-25].

Dietary intake during early childhood and beyond is impacted by complex intersections of individual behavior factors, like food preferences [26], and broader cultural, environmental, and socioeconomic factors, including race, ethnicity, gender, and education [27-29]. As such, healthy eating policies in ECE can take on many forms depending on their targeted outcome, which may include changes to child or provider eating behaviors, the food environment, mealtime practices, or knowledge and resources needed to provide healthier foods [13,30]. Differences in how governments regulate and administer child care also contribute to the heterogeneity in the design and implementation of healthy eating policies in ECE [31-33]. Given this heterogeneity, evaluations and subsequent literature reviews have been unable to identify strong, generalizable evidence to improve policy design and implementation $[30,34,35]$. This is partially because a significant proportion of this evidence focuses on local pilot programs rather than broader policies, which may be more difficult to evaluate due to resource constraints or challenges with measuring changes over time [30,34,35]. Researchers, experts, and stakeholders have correspondingly called for higher-quality evaluations of healthy eating policies in ECE [32,36], with a specific focus on the importance of natural experiments to evaluate policy impacts over time [37].

Therefore, the purpose of this study was to evaluate the impact of a state-level healthy eating policy on the diet quality of children in ECE. The study took place in South Carolina (SC) in the United States (USA). We used North Carolina (NC), a bordering state with no contemporaneous policy change, as the comparison. We hypothesized that children in ECE centers subject to the policy would improve overall and specific components of their diet quality, with no corresponding improvement in children in ECE centers in the comparison state.

\section{Materials and Methods}

\subsection{Overview}

This study analyzed the dietary intake of preschool-aged children in South Carolina ECE centers before and after the implementation of a healthy eating policy. We conducted a two-group pretest/post-test study and used North Carolina, where no policy changes occurred, as the comparison. We collected baseline and follow-up data in the same centers but not necessarily among the same children. Centers were eligible for participation in this study if they received state subsidies for providing care to low-income children through a statewide program and had no open case of abuse or neglect with the state licensing agency. We mailed recruitment letters to all eligible ECE directors (174 in SC, 168 in NC), and enrolled the first 30 who responded from each state. The research team enrolled an additional four centers in South Carolina to accommodate a high interest in participating among center directors. We obtained written, informed consent from ECE center directors and notified all parents of study procedures prior to collecting data. We did not collect any identifiable information related to individual children. The Institutional Review Boards of the University of South Carolina (\#00014606) and Duke University (\#00033793) approved this study, both in 2012.

\subsection{Policy in South Carolina}

The policy was implemented in April 2012 in South Carolina ECE centers by the Department of Social Services through a quality rating and improvement system (QRIS) called ABC Quality [38]. All participating centers were required to follow this new policy by October 2012 as part of their 
licensing requirements. The policy was designed to improve nutrition-related health outcomes for children ages 5 years and younger. The design and implementation of this policy included expert and stakeholder input from researchers, policymakers, and ECE providers, and has been described in detail elsewhere [39]. Centers were required to serve specific foods and beverages to children to comply with the policy. Children aged two years and older were required to be served skim or $1 \%$ milk only; one four-ounce serving of $100 \%$ fruit juice per day or water, two whole fruits, at least one vegetable (not including white potatoes), and at least one serving of whole grains. High-fat meats and sweet food items (e.g., cookies, cakes) were limited to two servings per week, and fried vegetables were limited to one serving per week. Additionally, ECE staff were required to attend annual nutrition trainings, implement age-appropriate nutrition lessons at least weekly in the classroom, and were prohibited from using food as a reward or punishment. All participating centers also needed to create and implement a written nutrition policy.

\subsection{Outcome}

We collected baseline dietary intake data during the two months preceding the policy implementation and then three months after its implementation, using the previously-validated Diet Observation in Child Care methodology [40,41]. Details of this method are available elsewhere [40-43]. Briefly, we trained and certified data collectors using pre-specified inter-rater reliability requirements, who then recorded all foods and beverages served to and eaten by children in each participating ECE center. Data collectors randomly selected up to three children in one classroom per center to observe throughout one day of regular care. Following pre-specified protocol, data collectors counted off all children present in the classroom and chose the first, third, and fifth child, with the seventh, if present, as an alternate [41]. We did not necessarily collect dietary intake data from the same children at baseline and follow-up since we were primarily interested in center-level dietary intake. Data collectors recorded all foods and beverages served to and consumed by children with as much detail as possible, including foods traded, discarded, and remaining at the end of all meals and snacks. The data collectors do not interact with children during the observations and are trained to discretely monitor selected children [41]. During observations, data collectors record distinguishing characteristics (e.g., "blue shirt") on collection forms to easily identify selected children and situate themselves in the classroom in such a way that all children may be observed simultaneously [41]. Data collectors recorded all recipes of foods prepared onsite and brand names of pre-packaged foods and beverages. The research team inputted these data into the Nutrition Database for Scientific Research version 2012 (Nutrition Coordination Center, University of Minnesota, Minneapolis, MN, USA) [44]. A trained researcher reviewed all dietary records for completeness and accuracy prior to exporting files for further analyses.

To assess diet quality, we calculated Healthy Eating Index (HEI) scores for all foods and beverages consumed by children in centers. We used the most recent scoring standards, updated in 2015 [45]. The HEI is a calorie-adjusted comparison of individual or group-level dietary intake to current dietary guidelines [46]. The HEI score was updated in 2015 and represents the sum of thirteen component scores. Higher scores are awarded for healthier intake within each component. The HEI components and maximum scores include total fruit (5), whole fruit (5), total vegetables (5), greens and beans (5), whole grains (10), dairy (10), total proteins (5), seafood/plant (lean) proteins (5), fatty acids (10), refined grains (10), sodium (10), added sugars (10), and saturated fats (10). To calculate these component scores, dietary data is expressed as a ratio per 1000 kilocalories, except for the fatty acids component, which is calculated as a ratio of polyunsaturated and monounsaturated fatty acids to saturated fatty acids. Higher consumption of food items within each component receives a higher score except for refined grains, sodium, added sugars, and saturated fats, which receive higher scores for lower intake. We applied the population ratio method to calculate and compare HEI scores between the two states, which utilizes mean dietary intake data and calculates scores at the group-level [46]. The population ratio method is recommended to calculate HEI scores at the population or sub-population level and to 
compare differences between groups. We utilized this method because we were interested in overall diet quality in ECE centers before and after the implementation of the policy.

\subsection{Other Measures}

During baseline data collection, directors from each ECE center completed a brief survey related to center characteristics. Directors reported total enrollment by age, number of income-subsidized children, total years in operation, number of teachers and classrooms, participation status in the Child and Adult Care Food Program (CACFP), profit status (for profit vs. non-profit), and child race and ethnicity as a percent of total enrollees. Directors also reported their highest level of education, and age, race, ethnicity, and gender.

\subsection{Analysis}

We calculated means, standards deviations, and proportions to summarize center characteristics. To evaluate the impact of the policy, we fit mixed-effects linear regression models [47] to estimate the difference, by state, in the change from baseline to post-policy HEI scores of foods consumed (primary outcome) and HEI component scores (secondary outcome). To calculate HEI scores from the Nutrition Database for Scientific Research output data, we implemented SAS software (SAS Institute Inc., Cary, NC, USA) scripts developed by the Nutrition Coordinating Center at the University of Minnesota [48] using R Statistical Software version 3.5.1 (R Foundation for Statistical Computing, Vienna, Austria). We included indicators for time, state, and an interaction between time and state (difference-in-difference estimator) in all models. We conducted unadjusted analyses and adjusted analyses using fixed effects for covariates identified a priori based on prior literature (child race, number of children enrolled, director education, center years in operation, participation in CACFP, and profit status) [49-51]. Due to missing covariate data, two centers were excluded from adjusted analyses. We included center random effects and robust standard errors in all models. We assessed the potential influence of extreme cases using multiple metrics (e.g., Cook's D, studentized residuals) and conducted sensitivity analyses excluding influential cases. We conducted these analyses using Stata/IC version 14.1 (StataCorp LLC, College Station, TX, USA) and a significance level of $p<0.05$.

\section{Results}

We observed 102 children from 34 centers in South Carolina and 90 children from 30 centers in North Carolina at baseline. At follow up, we observed 99 children at 33 centers in South Carolina and 78 children at 26 centers in North Carolina; five centers closed or withdrew during the study period (four in North Carolina, one in South Carolina). Centers lost to follow-up were demographically similar to those included at follow-up (results not shown). At baseline, South Carolina ECE centers enrolled more 3- to 5-year-old children than North Carolina ECE centers (mean (SD) 46.0 (34.1) vs. 25.4 (23.1)), and a lower mean (SD) percentage of Hispanic/Latino(a) children (1.4\% (2.6) vs. 4.8\% (7.3)) (Table 1). More directors from South Carolina reported receiving a four-year degree or higher, compared to directors from North Carolina (72.7\% vs. $60.0 \%$ ), and fewer South Carolina ECE centers were for-profit, compared to North Carolina ECE centers ( $86.7 \%$ vs. $52.9 \%)$. There were no other significant differences in baseline demographic characteristics between the two states. These differences in demographic characteristics were detected in comparisons of North Carolina and South Carolina centers included at baseline and included at follow-up. Comparing centers included at follow-up, one additional difference emerged: South Carolina ECE centers had a higher mean percentage of Black children compared to North Carolina centers (at baseline: $60.5 \%$ vs. $42.6 \%, p=0.06$; at follow-up: $61.5 \%$ vs. $41.8 \%, p=0.05)$. 
Table 1. Baseline characteristics of the 64 ECE centers in the policy evaluation study by the state in 2012.

\begin{tabular}{|c|c|c|}
\hline & South Carolina $(\mathrm{n}=34)$ & North Carolina $(n=30)$ \\
\hline Center characteristic & \multicolumn{2}{|c|}{ Mean (SD) } \\
\hline Children Enrolled, 3-5 Years Old & $46.0(34.1)$ & $25.4(23.1)$ \\
\hline Subsidized Children & $26.5(31.3)$ & $19.7(17.6)$ \\
\hline Years in Operation & $18.2(12.9)$ & $18.3(17.1)$ \\
\hline Number of Teachers & $10.9(6.9)$ & $9.8(9.4)$ \\
\hline \multirow[t]{2}{*}{ Number of Classrooms } & $6.2(3.1)$ & $5.3(3.0)$ \\
\hline & \multicolumn{2}{|c|}{$\%(\mathrm{~N})$} \\
\hline \multirow[t]{2}{*}{ For-Profit Status } & $52.9(18)$ & $86.7(26)$ \\
\hline & \multicolumn{2}{|c|}{ Mean (SD) } \\
\hline \multicolumn{3}{|l|}{ Child Race/Ethnicity } \\
\hline$\%$ Black/African American & $60.5(40.8)$ & $42.6(32.6)$ \\
\hline$\%$ Asian/Pacific Islander & $0.3(0.6)$ & $4.6(15.1)$ \\
\hline$\%$ White & $32.1(37.3)$ & $39.9(32.8)$ \\
\hline \% Hispanic/Latino(a) & $1.4(2.6)$ & $4.8(7.3)$ \\
\hline \% Multiple Races & $5.0(17.4)$ & $6.9(11.7)$ \\
\hline$\%$ Native American & $0.03(0.2)$ & $0.03(0.2)$ \\
\hline \multirow[t]{2}{*}{$\%$ Other Race } & $0.03(0.2)$ & $0.03(0.2)$ \\
\hline & \multicolumn{2}{|c|}{$\%(\mathrm{~N})$} \\
\hline \multicolumn{3}{|l|}{ Director education } \\
\hline High school/Community College & $27.3(9)$ & $40.0(12)$ \\
\hline Some or all 4-Year College & $33.3(11)$ & $53.3(16)$ \\
\hline More Than 4-Year College & $39.4(13)$ & $6.7(2)$ \\
\hline
\end{tabular}

At baseline, children had a mean (SD) HEI of 56.0 (11.5) in South Carolina and 55.9 (10.2) in North Carolina, out of 100 possible points (Table 2). At follow-up, South Carolina children increased HEI scores by 4.3 points to 60.3 , whereas North Carolina scores increased by 2.0 points to 57.8 . After adjustment, there was a non-significant increase in total HEI score of 3.1 points ( $95 \% \mathrm{CI}:-4.2$, 10.5; $p=0.41$ ) in South Carolina compared to North Carolina (Table 2). However, children's HEI component scores in South Carolina increased significantly for total fruits (0.8 points; $95 \%$ CI: 0.2, 1.5; $p=0.01$ ), whole fruits (0.9 points; $95 \%$ CI: $0.06,1.8 ; p=0.04)$, and seafood/plant proteins (1.2 points; 95\%CI: 0.06, 2.3; $p=0.04)$, compared to children in North Carolina. Children in South Carolina scored lower on the HEI dairy component score after the implementation of the policy, for an overall adjusted difference-in-difference of -1.3 points $(95 \% \mathrm{CI}:-2.3,-0.3 ; p=0.01)$. There were no other significant differences in HEI component scores between the two groups.

Findings were similar in magnitude and statistical significance across unadjusted and adjusted analyses. (Table A1) We did not identify any extreme values and findings were robust to sensitivity analyses excluding influential cases (results not shown). 
Table 2. Adjusted ${ }^{a}$ differences ${ }^{b}$ in Healthy Eating Index (HEI) total and component scores in children in South Carolina ECE centers post-policy, compared to North Carolina $(n=62)$.

\begin{tabular}{|c|c|c|c|c|c|c|c|}
\hline \multirow[b]{2}{*}{ Healthy Eating Index (Max Score) } & \multicolumn{2}{|c|}{ South Carolina (Policy) } & \multicolumn{2}{|c|}{ North Carolina (Comparison) } & \multirow[b]{2}{*}{$\begin{array}{l}\text { Difference-in- } \\
\text { Difference }\end{array}$} & \multirow[b]{2}{*}{$\begin{array}{c}p \\
\text { Value }\end{array}$} & \multirow[b]{2}{*}{$95 \% \mathrm{CI}$} \\
\hline & Baseline & Follow-Up & Baseline & Follow-Up & & & \\
\hline \multicolumn{8}{|l|}{ Adequacy Components } \\
\hline Total Score (100) & 56.0 & 60.3 & 55.8 & 57.8 & 3.1 & 0.41 & $-4.2,10.5$ \\
\hline Total Fruits (5) & 3.9 & 4.5 & 4.6 & 4.4 & 0.8 & 0.01 & $0.2,1.5$ \\
\hline Whole Fruits (5) & 4.3 & 4.5 & 4.6 & 4.0 & 0.9 & 0.04 & $0.06,1.8$ \\
\hline Total Vegetables (5) & 2.1 & 1.9 & 2.0 & 1.5 & 0.1 & 0.84 & $-0.8,1.0$ \\
\hline Greens and Beans (5) & 1.4 & 1.2 & 0.9 & 0.6 & -0.2 & 0.77 & $-1.4,1.1$ \\
\hline Whole Grains (10) & 2.4 & 3.2 & 2.2 & 3.1 & 0.1 & 0.91 & $-2.1,2.4$ \\
\hline Dairy (10) & 9.9 & 9.1 & 9.4 & 9.9 & -1.3 & 0.01 & $-2.3,-0.3$ \\
\hline Total Protein Foods (5) & 3.0 & 3.2 & 3.6 & 2.7 & 1.1 & 0.11 & $-0.3,2.4$ \\
\hline Seafood \& Plant Proteins (5) & 1.1 & 1.3 & 1.3 & 0.2 & 1.2 & 0.04 & $0.06,2.3$ \\
\hline Fatty Acids (10) & 1.9 & 4.1 & 3.0 & 4.5 & 0.9 & 0.42 & $-1.3,3.03$ \\
\hline \multicolumn{8}{|l|}{ Moderation Components } \\
\hline Refined Grains (10) & 6.7 & 6.0 & 5.3 & 5.4 & -0.7 & 0.55 & $-2.9,1.5$ \\
\hline Sodium (10) & 5.2 & 5.3 & 4.6 & 5.8 & -0.7 & 0.55 & $-3.1,1.7$ \\
\hline Added Sugars (10) & 8.0 & 8.1 & 7.9 & 8.2 & -0.1 & 0.94 & $-2.0,1.9$ \\
\hline Saturated Fats (10) & 6.1 & 7.7 & 6.3 & 7.4 & 0.9 & 0.43 & $-1.3,3.1$ \\
\hline
\end{tabular}

a Adjusted for child race, number of children 3-5 years enrolled, director education, number of years center has been in operation, participation in the Child and Adult Care Food Program, and center profit status. ${ }^{b}$ Models account for clustering within centers by clustering standard errors at the center level. Results are reported as predicted probabilities and marginal effects. 


\section{Discussion}

In this prospective evaluation of a healthy eating policy targeting low-income children in ECE in South Carolina, we found that children's overall diet quality did not improve significantly three months after the policy. However, children in centers subject to the policy improved their intake of fruit and lean proteins, compared to children in centers with no such policy. The healthy eating policy specifically targeted fruit and lean protein consumption, and thus these changes are in the anticipated direction.

The finding that total HEI scores (overall diet quality) did not improve is not expected. Overall HEI scores in children in both states were relatively low (about 60 out of 100 possible points) but consistent with prior observations of children's dietary intake in ECE centers [21,52-54] and family child care homes $[55,56]$. In these studies, consistent with our findings, children scored highest in whole fruit, total fruit, and dairy components. These overall findings reiterate the need to improve children's dietary intake in ECE, with a focus on other dietary components like vegetables and whole grains-components for which we did not see improvement.

Children in ECE centers subject to the policy significantly improved their intake of total and whole fruit. Increasing fruit consumption among young children is an important public health goal since many do not currently receive adequate servings of fruit [57], and those who do may be less likely to become overweight or obese [58] and have decreased all-cause mortality across the lifespan [59]. Pooled results from prospective cohort studies show this relationship to reach its peak at five daily servings of fruits and vegetables [59], which is consistent with USA and European Union dietary guidelines for children $[60,61]$. In this study, we observed total and whole fruit component scores at or above four out of five possible points, which is consistent with prior evidence of children's fruit consumption in ECE [21,52-54,56]. There is additional evidence that children consume more fruit in ECE than at home [62], which may be partially explained by the broader observation that children exhibit less picky eating behaviors in ECE versus at home [63]. The ECE environment may thus provide an important venue to expose children to a variety of foods and improve and maintain a healthy consumption of fruit among young children. Healthy eating policies that encourage taste tests and exposure to a variety of fruits may increase consumption in ECE, but more research is needed to better understand this relationship [35].

Children in centers subject to the policy also improved their consumption of seafood and plant proteins. There is reason to focus on protein sources, rather than protein as a single macronutrient, in young children's diets. First, the transition from infancy to toddlerhood is associated with a diversification of nutrient sources, during which many plant and animal foods replace formula or breastmilk as primary sources of protein [64]. There is longitudinal evidence of an association between protein sources and adiposity among children ages birth to 5 years, with collective results suggesting that lean proteins, particularly vegetable proteins, may be protective against excess body weight $[65,66]$. Protein sources are thus an important target of healthy eating policies in ECE, in light of prior evidence that children in these settings do not consume adequate amounts of lean proteins $[52,54,56]$. Although lean protein consumption improved in ECE centers that implemented the policy, overall scores remained low, reaching a maximum of only 1.3 out of 5 possible points. Importantly, component scores for lean proteins were lower than scores for total proteins. There is therefore room to improve sources of proteins in foods served to children in ECE. Moreover, healthy eating policies in ECE should seek to align with best practice recommendations to reduce consumption of high-fat meats like pre-fried nuggets [67]. Replacing high-fat meats with leaner options may provide an additional micronutrient benefit since lean proteins are typically richer in zinc, iron, and potassium, all of which tend to be consumed in inadequate amounts among young children [64].

We found that HEI component scores for dairy consumption decreased among children in intervention centers. Overall, dairy HEI scores remained high (>9/10) among children in intervention and comparison states before and after policy implementation, and prior studies have similarly reported high dairy HEI component scores among children in ECE [21,52-54,56]. The dairy component score 
included all fluid milk, cheese, and yogurt, but prior research suggests that young children in ECE receive most of their dairy intake from fluid milk [68]. Milk is a primary source of total caloric intake among young children [69], and recent studies showed most children consumed plain, unflavored, reduced-fat $(2 \%)$, or low-fat (1\%) milk in ECE [53,62,70]. This slight decrease in HEI component score may be partially attributable to decreases in servings of milk in South Carolina centers, possibly in response to nutrition rules that required serving only low- or non-fat milk. It is also possible that children require more time to shift to changes in what type of milk they are served in ECE. Still, replacing full or reduced-fat $(2 \%)$ milk with low or non-fat milk still provides children with necessary nutrients, like calcium, vitamin D, and potassium, but without excess calories and fat [71].

There are a variety of data collection methods and research designs used to evaluate healthy eating policies in ECE. In an evaluation of a statewide healthy eating policy in Delaware (USA), researchers found significant variation in compliance (but not child dietary intake) with different dietary components, with the majority of centers complying with juice regulations but less than one out of five complying with whole-grain requirements [72]. Identifying patterns and predictors of compliance with healthy eating policies in ECE may improve future policy design, but cannot measure policy impacts over time [73]. Other studies have described associations between ECE policies and child outcomes using retrospective methods, but these too are unable to assess changes over time. For example, in 2018, researchers evaluated correlations between local- and state-level childhood healthy eating and physical activity policies and obesity rates [74] and found that the 4 pre-selected study locations with declining childhood obesity rates had contemporaneously enacted relevant policies [75]. This scoping retrospective described general relationships between the policy environment and childhood obesity, but could not, as the authors noted, elucidate causal pathways [75]. Cross-sectional or retrospective evaluations may yield rich quantitative and qualitative data about healthy eating in ECE [76], but changes over time cannot be assessed and thus policy impacts remain unmeasured.

Several studies have addressed this gap and prospectively measured changes to children's diet before and after the implementation of new policies in ECE. In California (USA), for example, researchers administered comprehensive surveys to a random sample of ECE directors before and after the implementation of the healthy beverage policy [77]. Results from this prior evaluation showed significant improvements to the beverages served in ECE centers after the implementation of a policy [77], with a specific increase in the availability of water, which was a direct policy target [78]. The results from our study exceed the scope of prior prospective evaluations by collecting directly observed dietary intake data and including a comparison group to control for secular changes, which may be particularly important when studying natural experiments of policy changes in ECE. One recent study evaluating a new statewide physical activity policy in ECE found significant improvements in children's physical activity within the intervention state, but could not link these changes to the new policy, given similar improvements over time in a bordering state [79]. Considering its data collection methods and design, our study represents one of the most rigorous evaluations of a state healthy eating policy in ECE.

Our study also has limitations. First, we evaluated a natural experiment and thus were not able to randomize states to intervention (policy) or control. It is possible that there were differences between the two states that could account for some of our findings. Additionally, North Carolina could have made changes unbeknownst to our study team that influenced our results. However, given that we were not able to randomize, our quasi-experimental research design is recommended to account for secular changes when assessing the impact of a nutrition policy on dietary quality [37]. Next, five sites, including four in North Carolina and one in South Carolina were lost to follow-up; these sites, however, were demographically similar to those not lost to follow-up. Additionally, our dietary assessment method has limitations. We did not conduct plate waste studies, which have been used to describe diet quality in ECE [80] and provide researchers with a more precise estimate of dietary intake versus direct observation methods [81]. However, our observation method has been tested for both reliability and validity [41] and is considered a robust measurement technique in ECE [36]. 
Moreover, researchers often rely on survey or self-reported data from parents and providers to assess changes in children's dietary intake [82], which are useful for some research purposes [83] but do not yield levels of detail and accuracy gained from more other methods like weighing and measuring foods or directly observing meals and snacks in ECE [36,40]. We evaluated children's dietary intake via direct observation methods, which provide details and reductions in social desirability bias common in self-report survey data [84]. These methods are less common, and few evaluations of healthy eating policies have employed them [82], likely because of their associated costs and high staffing burden [36].

We did not necessarily collect dietary intake data from the same children in each center during baseline and follow-up and therefore could not account for the potential impact of picky eating or food neophobia. However, in a prior study, fewer than $20 \%$ of center directors in South Carolina reported children's taste preferences as a barrier to implementing the policy [85]. In the same study, directors reported cost as the most prevalent barrier [85], which adds to evidence that resource and environmental barriers are often reported during implementation studies of healthy eating policies in ECE [86]. Still, it is important to note that more than half of all directors who implemented this policy in South Carolina reported perceptions of being well-informed about the policy components and their likely impact on day-to-day changes in ECE [85]. Future studies should continue to assess resource barriers to implementing new healthy eating policies in ECE, which may ultimately impact intended policy effects [34]. We also conducted follow-up assessments relatively soon after the policy was implemented. Due to limited funding, we were not able to assess the longer-term implications of the policy. Finally, ours was a relatively small convenience sample of children and centers, which limits the generalizability of our findings. Despite this, our study is one of the first to prospectively evaluate a new statewide healthy eating policy in ECE, employing more robust data collection methods and a comparison group. Future studies could include larger numbers of centers and children to increase the generalizability of findings.

\section{Conclusions}

Children exposed to the policy in South Carolina exhibited modest improvements in some components of their diets, but the policy did not appear to impact overall diet quality as measured by the HEI. Healthy eating policies in ECE have the potential to improve children's diet quality and may be an important intervention to improve health and reduce childhood obesity. Future research should assess the impacts of healthy eating policies in the longer term, making use of larger sample sizes and longer follow-up periods.

Author Contributions: Conceptualization, S.E.B.-N. and R.R.P.; Methodology, S.E.B.-N.; R.R.P.; and B.N.; Formal Analysis, D.A.Z.; A.A.H.; and B.N.; Investigation, S.E.B.-N.; R.R.P.; Resources, S.E.B.-N.; Data curation, D.A.Z. and A.A.H.; Writing-Original Draft Preparation, D.A.Z.; Writing-Review and Editing, D.A.Z.; R.A.N.; A.A.H.; R.R.P.; B.N.; J.R.O.; S.E.B.-N.; Supervision, S.E.B.-N.; R.A.N.; J.R.O.; and R.R.P.; Project Administration, S.E.B.-N.; J.R.O.; Funding Acquisition, S.E.B.-N.; R.A.N.; and R.R.P. All authors have read and agreed to the published version of the manuscript.

Funding: This study was supported, in part, by a grant from the Robert Wood Johnson Foundation (RWJF), Healthy Eating Research \#69551; The content is solely the responsibility of the authors and does not necessarily represent the official views of the RWJF. This study was funded by a grant from the Bloomberg American Health Initiative (no grant number). RN's time was partially supported by the Columbia Foundation (no grant number). AAH's time was partially supported by the Center for a Livable Future-Lerner fellowships. DAZ's time was partially supported by a grant from the National Institutes of Health T32DK062707. The funders had no role in selection of study topic, research design, analysis, or interpretation of the findings.

Conflicts of Interest: The authors declare no conflict of interest. The funders had no role in the design of the study; in the collection, analyses, or interpretation of data; in the writing of the manuscript, or in the decision to publish the results. 


\section{Appendix A}

Table A1. Unadjusted $(n=64)$ and adjusted ${ }^{a}(n=62)$ differences ${ }^{b}$ in Healthy Eating Index (HEI) total and component scores in children in South Carolina ECE centers post-policy, compared to North Carolina.

\begin{tabular}{|c|c|c|c|c|c|}
\hline & Unadjustec & & Adjusted & & \\
\hline Healthy Eating Index (Max Score) & Difference-in-Difference & $p$ Value & $\begin{array}{l}\text { Difference-in- } \\
\text { Difference }\end{array}$ & $\begin{array}{c}p \\
\text { Value }\end{array}$ & $95 \% \mathrm{CI}$ \\
\hline \multicolumn{6}{|l|}{ Adequacy Components } \\
\hline Total Score (100) & 2.4 & 0.52 & 3.1 & 0.41 & $-4.2,10.5$ \\
\hline Total Fruits (5) & 0.8 & 0.02 & 0.8 & 0.01 & $0.2,1.5$ \\
\hline Whole Fruits (5) & 0.9 & 0.03 & 0.9 & 0.04 & $0.06,1.8$ \\
\hline Total Vegetables (5) & 0.2 & 0.58 & 0.1 & 0.84 & $-0.8,1.0$ \\
\hline Greens and Beans (5) & 0.03 & 0.96 & -0.2 & 0.77 & $-1.4,1.1$ \\
\hline Whole Grains (10) & -0.06 & 0.96 & 0.1 & 0.91 & $-2.1,2.4$ \\
\hline Dairy (10) & -1.3 & 0.01 & -1.3 & 0.01 & $-2.3,-0.3$ \\
\hline Total Protein Foods (5) & 1.1 & 0.12 & 1.1 & 0.11 & $-0.3,2.4$ \\
\hline Seafood \& Plant Proteins (5) & 1.3 & 0.02 & 1.2 & 0.04 & $0.06,2.3$ \\
\hline Fatty Acids (10) & 0.70 & 0.52 & 0.9 & 0.42 & $-1.3,3.03$ \\
\hline \multicolumn{6}{|l|}{ Moderation Components } \\
\hline Refined Grains (10) & -0.75 & 0.50 & -0.7 & 0.55 & $-2.9,1.5$ \\
\hline Sodium (10) & -1.04 & 0.39 & -0.7 & 0.55 & $-3.1,1.7$ \\
\hline Added Sugars (10) & -0.18 & 0.85 & -0.1 & 0.94 & $-2.0,1.9$ \\
\hline Saturated Fats (10) & 0.57 & 0.62 & 0.9 & 0.43 & $-1.3,3.1$ \\
\hline
\end{tabular}

${ }^{\text {a }}$ Adjusted for child race, number of children 3-5 years enrolled, director education, number of years center has been in operation, participation in the Child and Adult Care Food Program, and center profit status. ${ }^{b}$ Models account for clustering within centers by clustering standard errors at the center level. Results are reported as predicted probabilities and marginal effects.

\section{References}

1. Ng, M.; Fleming, T.; Robinson, M.; Thomson, B.; Graetz, N.; Margono, C.; Mullany, E.C.; Biryukov, S.; Abbafati, C.; Abera, S.F.; et al. Global, regional, and national prevalence of overweight and obesity in children and adults during 1980-2013: A systematic analysis for the Global Burden of Disease Study 2013. Lancet 2014, 384, 766-781. [CrossRef]

2. Hruby, A.; Hu, F.B. The Epidemiology of Obesity: A Big Picture. Pharmacoeconomics 2015, 33, 673-689. [CrossRef]

3. Freedman, D.S.; Mei, Z.; Srinivasan, S.R.; Berenson, G.S.; Dietz, W.H. Cardiovascular risk factors and excess adiposity among overweight children and adolescents: The Bogalusa Heart Study. J. Pediatr. 2007, 150, 12-17 e2. [CrossRef]

4. Ford, E.S. The epidemiology of obesity and asthma. J. Allergy Clin. Immunol. 2005, 115, 897-909. [CrossRef]

5. Hannon, T.S.; Rao, G.; Arslanian, S.A. Childhood obesity and type 2 diabetes mellitus. Pediatrics 2005, 116, 473-480. [CrossRef]

6. Singh, A.S.; Mulder, C.; Twisk, J.W.R.; van Mechelen, W.; Chinapaw, M.J.M. Tracking of childhood overweight into adulthood: A systematic review of the literature. Obes. Rev. 2008, 9, 474-488. [CrossRef]

7. Pont, S.J.; Puhl, R.; Cook, S.R.; Slusser, W. Section on Obesity; Obesity Society. Stigma experienced by children and adolescents with obesity. Pediatrics 2017, 140, e20173034. [CrossRef]

8. Reilly, J.J.; Kelly, J. Long-term impact of overweight and obesity in childhood and adolescence on morbidity and premature mortality in adulthood: Systematic review. Int. J. Obes. (Lond.) 2011, 35, 891-898. [CrossRef]

9. Freedman, D.S.; Khan, L.K.; Dietz, W.H.; Srinivasan, S.R.; Berenson, G.S. Relationship of childhood obesity to coronary heart disease risk factors in adulthood: The Bogalusa Heart Study. Pediatrics. 2001, 108, 712-718. [CrossRef] 
10. Buscot, M.J.; Thomson, R.J.; Juonala, M.; Sabin, M.A.; Burgner, D.P.; Lehtimäki, T.; Hutri-Kähönen, N.; Viikari, J.S.A.; Jokinen, E.; Tossavainen, P.; et al. BMI trajectories associated with resolution of elevated youth BMI and incident adult obesity. Pediatrics 2018, 141, e20172003. [CrossRef]

11. Gortmaker, S.L.; Swinburn, B.A.; Levy, D.; Carter, R.; Mabry, P.L.; Finegood, D.T.; Huang, T.; Marsh, T.; Moodie, M.L. Changing the future of obesity: Science, policy, and action. Lancet 2011, 378, 838-847. [CrossRef]

12. Bleich, S.N.; Vercammen, K.A.; Zatz, L.Y.; Frelier, J.M.; Ebbeling, C.B.; Peeters, A. Interventions to prevent global childhood overweight and obesity: A systematic review. Lancet Diabetes Endocrinol. 2018, 6, 332-346. [CrossRef]

13. Larson, N.; Ward, D.S.; Neelon, S.B.; Story, M. What role can child-care settings play in obesity prevention? A review of the evidence and call for research efforts. J. Am. Diet. Assoc. 2011, 111, 1343-1362. [CrossRef]

14. OECD. Starting Strong 2017-Key OECD Indicators on Early Childhood Education and Care; OECD: Paris, France, 2017.

15. Corcoran, L.; Steinley, K. Early Childhood Program Participation, Results from the National Household Education Surveys Program of 2016 (NCES 2017-101.REV); National Center for Education Statistics, Institute of Education Sciences, US Department of Education: Washington, DC, USA, 2019.

16. Geoffroy, M.C.; Power, C.; Touchette, E.; Dubois, L.; Boivin, M.; Séguin, J.R.; Tremblay, R.E.; Côté, S.M. Childcare and overweight or obesity over 10 years of follow-up. J. Pediatr. 2013, 162, 753-758 e1. [CrossRef]

17. Gubbels, J.; Kremers, S.P.J.; Stafleu, A.; Dagnelie, P.C.; de Vries, N.K.; van Buuren, S.; Thijs, C. Child-care use and the association with body mass index and overweight in children from 7 months to 2 years of age. Int. J. Obes. (Lond.) 2010, 34, 1480-1486. [CrossRef]

18. Benjamin, S.E.; Rifas-Shiman, A.L.; Taveras, E.M.; Haines, J.; Finkelstein, J.; Kleinman, K.; Gillman, M.W. Early Child Care and Adiposity at Ages 1 and 3 Years. Pediatrics 2009, 124, 555-562. [CrossRef]

19. Gubbels, J.S.; Raaijmakers, L.G.M.; Gerards, S.M.P.L.; Kremers, S.P.J. Dietary intake by Dutch 1- to 3-year-old children at childcare and at home. Nutrients 2014, 6, 304-318. [CrossRef]

20. Neelon, S.E.B.; Burgoine, T.; Hesketh, K.R.; Monsivais, P. Nutrition practices of nurseries in England. Comparison with national guidelines. Appetite 2015, 85, 22-29. [CrossRef]

21. Erinosho, T.O.; Ball, S.C.; Hanson, P.P.; Vaughn, A.E.; Ward, D.S. Assessing Foods Offered to Children at Child-Care Centers Using the Healthy Eating Index-2005. J. Acad. Nutr. Diet. 2013, 113, 1084-1089. [CrossRef]

22. Roberts, C.; Steer, T.; Maplethorpe, N.; Cox, L.; Meadows, S.; Nicholson, S.; Page, P.; Swan, G. National Diet and Nutrition Survey: Results from Years 7 and 8 (Combined) of the Rolling Programme (2014/2015-2015/2016); Public Health England: London, UK, 2018.

23. Nicklaus, S.; Remy, E. Early Origins of Overeating: Tracking Between Early Food Habits and Later Eating Patterns. Curr. Obes. Rep. 2013, 2, 179-184. [CrossRef]

24. Rose, C.M.; Birch, L.L.; Savage, J.S. Dietary patterns in infancy are associated with child diet and weight outcomes at 6 years. Int. J. Obes. (Lond.) 2017, 41, 783-788. [CrossRef] [PubMed]

25. Rolland-Cachera, M.F.; Akrout, M.; Peneau, S. Nutrient Intakes in Early Life and Risk of Obesity. Int. J. Environ. Res. Public Health. 2016, 13, 564. [CrossRef] [PubMed]

26. Beauchamp, G.K.; Mennella, J.A. Early Flavor Learning and Its Impact on Later Feeding Behavior. J. Pediatr. Gastroenterol. Nutr. 2009, 48, S25-S30. [CrossRef] [PubMed]

27. Caprio, S.; Daniels, S.R.; Drewnowski, A.; Kaufman, F.R.; Palinkas, L.A.; Rosenbloom, A.L.; Schwimmer, J.B. Influence of race, ethnicity, and culture on childhood obesity: Implications for prevention and treatment: A consensus statement of Shaping America's Health and the Obesity Society. Diabetes Care 2008, 31, 2211-2221. [CrossRef]

28. Singh, G.K.; Siahpush, M.; Kogan, M.D. Neighborhood socioeconomic conditions, built environments, and childhood obesity. Health Affairs 2010, 29, 503-512. [CrossRef]

29. Mader, S.; Rubach, M.; Schaecke, W.; Röger, C.; Feldhoffer, I.; Thalmeier, E.-M. Healthy nutrition in Germany: A survey analysis of social causes, obesity and socioeconomic status. Public Health Nutr. 2020, 1-15. [CrossRef]

30. Matwiejczyk, L.; Mehta, K.; Scott, J.; Tonkin, E.; Coveney, J. Characteristics of Effective Interventions Promoting Healthy Eating for Pre-Schoolers in Childcare Settings: An Umbrella Review. Nutrients 2018, 10, 293. [CrossRef] 
31. Kaga, Y.; Bennett, J.; Moss, P. Caring and Learning Together: A Cross-National Study on the Integration of Early Childhood Care and Education Within Education; UNESCO: Paris, France, 2010; pp. 5-10.

32. Lucas, P.J.; Patterson, E.; Sacks, G.; Billich, N.; Evans, C.E.L. Preschool and School Meal Policies: An Overview of What We Know about Regulation, Implementation, and Impact on Diet in the UK, Sweden, and Australia. Nutrients 2017, 9, 736. [CrossRef]

33. Benjamin, S.E.; Cradock, A.; Walker, E.M.; Slining, M.; Gillman, M.W. Obesity prevention in child care: A review of U.S. state regulations. BMC Public Health 2008, 8, 188. [CrossRef]

34. Wolfenden, L.; Barnes, C.; Jones, J.; Finch, M.; Wyse, R.J.; Kingsland, M.; Tzelepis, F.; Grady, A.; Hodder, R.K.; Booth, D. Strategies to improve the implementation of healthy eating, physical activity and obesity prevention policies, practices or programmes within childcare services. Cochrane Database Syst. Rev. 2020, 2, Cd011779. [CrossRef]

35. Hodder, R.K.; O’Brien, K.M.; Stacey, F.G.; Wyse, R.J.; Clinton-McHarg, T.; Tzelepis, F.; James, E.L.; Bartlem, K.M.; Nathan, N.K.; Sutherland, R. Interventions for increasing fruit and vegetable consumption in children aged five years and under. Cochrane Database Syst. Rev. 2018, 5, CD008552.

36. Ward, D.S.; Vaughn, A.; Story, M. Expert and Stakeholder Consensus on Priorities for Obesity Prevention Research in Early Care and Education Settings. Child. Obes. 2013, 9, 116-124. [CrossRef]

37. Bowen, D.J.; Barrington, W.E.; Beresford, S.A.A. Identifying the Effects of Environmental and Policy Change Interventions on Healthy Eating. Annu. Rev. Public Health. 2015, 36, 289-306. [CrossRef]

38. ABC Quality. South Carolina Department of Social Services Early Care and Education Division. Available online: http://www.abcquality.org/what-is-abc-quality/ (accessed on 3 November 2019).

39. Benjamin Neelon, S.E.; Mayhew, M.; O’Neill, J.R.; Neelon, B.; Li, F.; Pate, R.R. Comparative Evaluation of a South Carolina Policy to Improve Nutrition in Child Care. J. Acad. Nutr. Diet. 2016, 116, 949-956. [CrossRef] [PubMed]

40. Ball, S.C.; Benjamin, S.E.; Ward, D.S. Development and reliability of an observation method to assess food intake of young children in child care. J. Am. Diet. Assoc. 2007, 107, 656-661. [CrossRef]

41. Benjamin, S.E.; Neelon, B.; Ball, S.C.; Bangdiwala, S.I.; Ammerman, A.S.; Ward, D.S. Reliability and validity of a nutrition and physical activity environmental self-assessment for child care. Int J Behav Nutr Phys Act. 2007, 4, 29. [CrossRef]

42. Ward, D.; Hales, D.; Haverly, K.; Marks, J.; Benjamin, S.; Ball, S.; Trost, S. An instrument to assess the obesogenic environment of child care centers. Am. J. Health Behav. 2008, 32, 380-386. [CrossRef]

43. Ammerman, A.S.; Ward, D.S.; Benjamin, S.E.; Ball, S.C.; Sommers, J.K.; Molloy, M.; Dodds, J.M. An intervention to promote healthy weight: Nutrition and Physical Activity Self-Assessment for Child Care (NAP SACC) theory and design. Prev. Chronic Dis. 2007, 4, A67.

44. Nutrition Database for Scientific Research (NDSR); University of Minnesota Nutrition Coordinating Council: Minneapolis, MN, USA, 2015; Available online: http://www.ncc.umn (accessed on 1 October 2019).

45. Krebs-Smith, S.M.; Pannucci, T.R.E.; Subar, A.F.; Kirkpatrick, S.I.; Lerman, J.L.; Tooze, J.A.; Wilson, M.M.; Reedy, J. Update of the Healthy Eating Index: HEI-2015. J. Acad. Nutr. Diet. 2018, 118, 1591-1602. [CrossRef]

46. National Cancer Institute Division of Cancer Control and Population Sciences. The Healthy Eating Index: Overview of the Methods $\mathcal{E}$ Calculations; National Institutes of Health: Bethesda, MD, USA, 2015. Available online: https://epi.grants.cancer.gov/hei/hei-methods-and-calculations.html (accessed on 12 November 2019).

47. Snijders, T.; Bosker, R. Multilevel Analysis: An Introduction to Basic and Advanced Multilevel Modeling, 2nd ed.; SAGE Publications Ltd: Los Angeles, CA, USA, 2012; pp. 41-73.

48. Nutrition Database for Scientific Research (NDSR). HEI SAS Macro. 2012; University of Minnesota Nutrition Coordinating Council: Minneapolis, MN, USA, 2012; Available online: https:/drive.google.com/a/umn.edu/ file/d/14R2I1PDy63Jfs-bt4-gCDr8clk16QPKD/view?usp=sharing. (accessed on 15 November 2019).

49. Korenman, S.; Abner, K.S.; Kaestner, R.; Gordon, R.A. The Child and Adult Care Food Program and the Nutrition of Preschoolers. Early Child. Res. Q. 2013, 28, 325-336. [CrossRef]

50. Chriqui, J.F.; Leider, J.; Schermbeck, R.M. Early Childhood Education Centers' Reported Readiness to Implement the Updated Child and Adult Care Food Program Meal Pattern Standards in the United States, 2017. Child. Obes. 2018, 14, 412-420. [CrossRef] [PubMed] 
51. Ward, S.; Bélanger, M.; Donovan, D.; Carrier, N. Systematic review of the relationship between childcare educators' practices and preschoolers' physical activity and eating behaviours. Obes. Rev. 2015, 16, 1055-1070. [CrossRef] [PubMed]

52. Luecking, C.T.; Mazzucca, S.; Vaughn, A.E.; Ward, D.S. Contributions of Early Care and Education Programs to Diet Quality in Children Aged 3 to 4 Years in Central North Carolina. J. Acad. Nutr. Diet. 2020, 120, 386-394. [CrossRef] [PubMed]

53. Romo-Palafox, M.J.; Ranjit, N.; Sweitzer, S.J.; Roberts-Gray, C.; Byrd-Williams, C.E.; Briley, M.E.; Hoelscher, D.M. Contribution of Beverage Selection to the Dietary Quality of the Packed Lunches Eaten by Preschool-Aged Children. J. Acad. Nutr. Diet. 2018, 118, 1417-1424. [CrossRef]

54. Kroeger, E.N.; Fernandez, J.; Jones, P.; Bertrand, B. Diet Quality in Early Care and Education Centers: A Comparison of Menu, Served, and Consumed Lunch Measures. J. Nutr. Educ. Behav. 2020, 52, 39-44. [CrossRef]

55. Benjamin-Neelon, S.E.; Vaughn, A.E.; Tovar, A.; Østbye, T.; Mazzucca, S.; Ward, D.S. The family child care home environment and children's diet quality. Appetite 2018, 126, 108-113. [CrossRef]

56. Tovar, A.; Benjamin-Neelon, S.E.; Vaughn, A.E.; Tsai, M.; Burney, R.; Østbye, T.; Ward, D.S. Nutritional Quality of Meals and Snacks Served and Consumed in Family Child Care. J. Acad. Nutr. Diet. 2018, 118, 2280-2286. [CrossRef]

57. Kim, S.A.; Moore, L.V.; Galuska, D.; Wright, A.P.; Harris, D.; Grummer-Strawn, L.M.; Merlo, C.L.; Nihiser, A.J.; Rhodes, D.G. Division of Nutrition, Physical Activity, and Obesity, National Center for Chronic Disease Prevention and Health Promotion, CDC. Vital signs: Fruit and vegetable intake among children-United States, 2003-2010. MMWR Morb. Mortal. Wkly. Rep. 2014, 63, 671-676.

58. ISAAC Phase Three Study Group; Wall, C.; Stewart, A.W.; Hancox, R.J.; Murphy, R.; Braithwaite, I.; Beasley, R.; Mitchell, E.A. Association between frequency of consumption of fruit, vegetables, nuts and pulses and BMI: Analyses of the International Study of Asthma and Allergies in Childhood (ISAAC). Nutrients 2018, 10, 316.

59. Wang, X.; Ouyang, Y.; Liu, J.; Zhu, M.; Zhao, G.; Bao, W.; Hu, F.B. Fruit and vegetable consumption and mortality from all causes, cardiovascular disease, and cancer: Systematic review and dose-response meta-analysis of prospective cohort studies. BMJ 2014, 349, g4490. [CrossRef]

60. 2015-2020 Dietary Guidelines for Americans, 8th ed. Available online: https://health.gov/our-work/foodnutrition/2015-2020-dietary-guidelines/guidelines/ (accessed on 4 February 2020).

61. Food-Based Dietary Guidelines in Europe. 2020. Available online: https://ec.europa.eu/jrc/en/ health-knowledge-gateway/promotion-prevention/nutrition/food-based-dietary-guidelines (accessed on 4 February 2020).

62. Sisson, S.B.; Kiger, A.C.; Anundson, K.C.; Rasbold, A.H.; Krampe, M.; Campbell, J.; DeGrace, B.; Hoffman, L. Differences in preschool-age children's dietary intake between meals consumed at childcare and at home. Prev. Med. Rep. 2017, 6, 33-37. [CrossRef]

63. Luchini, V.; Musaad, S.; Lee, S.-Y.; Donovan, S.M. Observed differences in child picky eating behavior between home and childcare locations. Appetite 2017, 116, 123-131. [CrossRef]

64. Grimes, C.A.; Szymlek-Gay, E.A.; Campbell, K.J.; Nicklas, T.A. Food Sources of Total Energy and Nutrients among U.S. Infants and Toddlers: National Health and Nutrition Examination Survey 2005-2012. Nutrients 2015, 7, 6797-6836. [CrossRef]

65. Günther, A.L.; Remer, T.; Kroke, A.; Buyken, A.E. Early protein intake and later obesity risk: Which protein sources at which time points throughout infancy and childhood are important for body mass index and body fat percentage at $7 \mathrm{y}$ of age? Am. J. Clin. Nutr. 2007, 86, 1765-1772. [CrossRef]

66. Voortman, T.; Braun, K.V.E.; Kiefte-de Jong, J.C.; Jaddoe, V.W.V.; Franco, O.H.; van den Hooven, E.H. Protein intake in early childhood and body composition at the age of 6 years: The Generation R Study. Int. J. Obes. (Lond.) 2016, 40, 1018. [CrossRef]

67. Benjamin-Neelon, S.E. Position of the Academy of Nutrition and Dietetics: Benchmarks for Nutrition in Child Care. J. Acad. Nutr. Diet. 2018, 118, 1291-1300. [CrossRef]

68. Keast, D.; Fulgoni, V.L., III; Nicklas, T.A.; O’Neil, C.E. Food sources of energy and nutrients among children in the United States: National Health and Nutrition Examination Survey 2003-2006. Nutrients 2013, 5, 283-301. [CrossRef]

69. Reedy, J.; Krebs-Smith, S.M. Dietary sources of energy, solid fats, and added sugars among children and adolescents in the United States. J. Am. Diet. Assoc. 2010, 110, 1477-1484. [CrossRef] 
70. Robson, S.M.; Khoury, J.C.; Kalkwarf, H.J.; Copeland, K. Dietary Intake of Children Attending Full-time Child Care: What are they eating away from the Child-Care Center? J. Acad. Nutr. Diet. 2015, 115, 1472-1478. [CrossRef]

71. Rehm, C.D.; Drewnowski, A.; Monsivais, P. Potential Population-Level Nutritional Impact of Replacing Whole and Reduced-Fat Milk with Low-Fat and Skim Milk Among US Children Aged 2-19 Years. J. Nutr. Educ. Behav. 2015, 47, 61-68 e1. [CrossRef]

72. Lessard, L.; Williams Leng, S.; Brennan, R. Consistency of compliance with nutrition-related regulations among Delaware child care centers. Child. Obes. 2013, 9, 233-239. [CrossRef]

73. Jones, J.; Yoong, S.L.; Wyse, R.; Ward, D.S.; Wolfenden, L. Improving the impact of obesity prevention interventions in the childcare setting: The need for a systematic application of implementation science. J. Paediatr. Child Health 2017, 53, 211-213. [CrossRef] [PubMed]

74. Kettel Khan, L.; Ottley, P.; Harris, C.; Dawkins-Lyn, N.; Dooyema, C.; Jernigan, J.; Kauh, T.; Young-Hyman, D. Childhood Obesity Declines Project: A Different Methodology. Child. Obes. 2018, 14, S5-S11. [CrossRef]

75. Dooyema, C.; Jernigan, J.; Warnock, A.L.; Dawkins-Lyn, N.; Harris, C.; Kauh, T.; Khan, L.K.; Ottley, P.; Young-Hyman, D. The Childhood Obesity Declines Project: A Review of Enacted Policies. Child. Obes. 2018, 14, S22-S31. [CrossRef]

76. Breck, A.; Goodman, K.; Dunn, L.; Stephens, R.L.; Dawkins, N.; Dixon, B.; Jernigan, J.; Kakietek, J.; Lesesne, C.; Laura Lessard, L.; et al. Evaluation design of New York City's regulations on nutrition, physical activity, and screen time in early child care centers. Prev. Chronic Dis. 2014, 11, E184. [CrossRef]

77. Ritchie, L.D.; Sharma, S.; Gildengorin, G.; Yoshida, S.; Braff-Guajardo, E.; Crawford, P. Policy improves what beverages are served to young children in child care. J. Acad. Nutr. Diet. 2015, 115, 724-730. [CrossRef]

78. Ritchie, L.D.; Yoshida, S.; Sharma, S.; Patel, A.; Vitale, E.H.; Hecht, K. Drinking Water in California child care sites before and after 2011-2012 beverage policy. Prev. Chron. Dis. 2015, 12, E89. [CrossRef]

79. Benjamin Neelon, S.E.; Finkelstein, J.; Neelon, B.; Gillman, M.W. Evaluation of a Physical Activity Regulation for Child Care in Massachusetts. Child Obes. 2017, 13, 36-43. [CrossRef]

80. Andreyeva, T.; Kenney, E.L.; O'Connell, M.; Sun, X.; Henderson, K.E. Predictors of Nutrition Quality in Early Child Education Settings in Connecticut. J. Nutr. Educ. Behav. 2018, 50, 458-467. [CrossRef]

81. Food and Nutrition Board; Institute of Medicine. Research Methods to Assess Dietary Intake and Program Participation in Child Day Care: Application to the Child and Adult Care Food Program: Workshop Summary; Pray, L., Yaktine, A., Moats, S., Eds.; The National Academies Press: Washington, DC, USA, 2012.

82. Sisson, S.B.; Krampe, M.; Anundson, K.; Castle, S. Obesity prevention and obesogenic behavior interventions in child care: A systematic review. Prev. Med. 2016, 87, 57-69. [CrossRef]

83. Subar, A.F.; Freedman, L.S.; Tooze, J.A.; Kirkpatrick, S.I.; Boushey, C.; Neuhouser, M.L.; Thompson, F.E.; Potischman, N.; Guenther, P.M.; Tarasuk, V.; et al. Addressing Current Criticism Regarding the Value of Self-Report Dietary Data. J. Nutr. 2015, 145, 2639-2645. [CrossRef] [PubMed]

84. Hebert, J.R.; Clemow, L.; Pbert, L.; Ockene, I.S.; Ockene, J.K. Social desirability bias in dietary self-report may compromise the validity of dietary intake measures. Int. J. Epidemiol. 1995, 24, 389-398. [CrossRef] [PubMed]

85. Zaltz, D.A.; Pate, R.R.; O'Neill, J.R.; Neelon, B.; Benjamin-Neelon, S.E. Barriers and Facilitators to Compliance with a State Healthy Eating Policy in Early Care and Education Centers. Child. Obes. 2018, 14, 349-357. [CrossRef]

86. Seward, K.; Finch, M.; Yoong, S.L.; Wyse, R.; Jones, J.; Grady, A.; Wiggers, J.; Nathan, N.; Conte, K.; Wolfenden, L. Factors that influence the implementation of dietary guidelines regarding food provision in centre based childcare services: A systematic review. Prev. Med. 2017, 105, 197-205. [CrossRef] [PubMed]

(C) 2020 by the authors. Licensee MDPI, Basel, Switzerland. This article is an open access article distributed under the terms and conditions of the Creative Commons Attribution (CC BY) license (http://creativecommons.org/licenses/by/4.0/). 